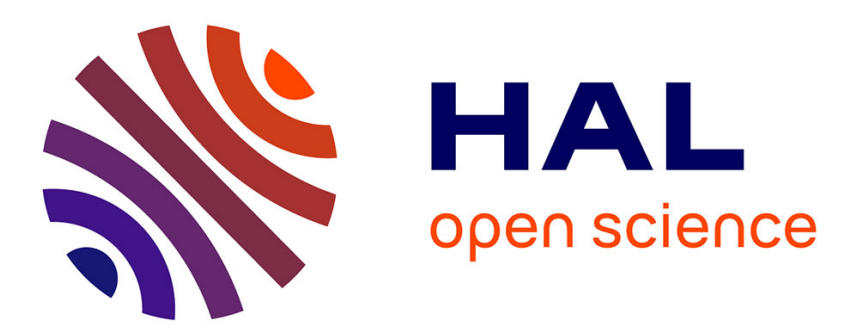

\title{
Ordering collective performance manipulation practices: How do leaders manipulate financial reporting figures in conglomerates?
}

François-Régis Puyou

\section{- To cite this version:}

François-Régis Puyou. Ordering collective performance manipulation practices: How do leaders manipulate financial reporting figures in conglomerates?. Critical Perspectives On Accounting, 2014, 25 (6), pp.469-488. 10.1016/j.cpa.2013.03.004 . hal-01069276

\section{HAL Id: hal-01069276}

https://hal-audencia.archives-ouvertes.fr/hal-01069276

Submitted on 9 Apr 2015

HAL is a multi-disciplinary open access archive for the deposit and dissemination of scientific research documents, whether they are published or not. The documents may come from teaching and research institutions in France or abroad, or from public or private research centers.
L'archive ouverte pluridisciplinaire HAL, est destinée au dépôt et à la diffusion de documents scientifiques de niveau recherche, publiés ou non, émanant des établissements d'enseignement et de recherche français ou étrangers, des laboratoires publics ou privés. 
Ordering collective performance manipulation practices:

How do leaders manipulate financial reporting figures in conglomerates?

François-Régis Puyou, Audencia Nantes

Published in Critical Perspectives on Accounting (2014), vol. 25, n6, 469-488

\begin{abstract}
:
This article explores some of the resources, tactics and skills used by managers involved in the manipulation of performance reporting by looking at management accounting practices in a conglomerate. Prior research on reporting manipulation in large corporations has focused on why executives manipulate figures. The present paper documents how BU leaders compensate for the uncertainties impacting the performance of their activities. Empirical evidence comes from a field study of a diversified French conglomerate. Performance reporting practices within and between a parent company and two subsidiaries are analyzed. The article shows that the conglomerate constitutes a strategic action field (Fligstein and McAdam 2011) where skilful group leaders use the resources granted by their power position to frame other actors' interests and identities to initiate stable cooperation around manipulation practices. This study clarifies the collective and collaborative dimensions of practices granting greater control over reporting figures.
\end{abstract}

Keywords: Fligstein; Management Control; Performance Manipulation; Social; 


\section{Introduction}

This article deals with performance manipulation practices within conglomerates. It contributes to existing literature on "profit manipulation" defined as "when managers of business components make self-beneficial choices of accounting methods or take action to influence economic events which impact reported profits" (Macintosh 1995: p.289). Prior studies have explored the antecedents of manipulation practices. Extant research tends to see performance manipulation practices as a way for opportunistic managers to gain personal benefits (e.g. Lambert 1984; Moses 1987) or as a resistance strategy against unreasonable financial expectations imposed by shareholders (e.g. Macintosh 1995; Lambert and Sponem 2005). Few studies have focused on how managers' control over performance indicators is enacted in practice. A better understanding of the resources, tactics, and skills involved in manipulation practices is needed to clarify the material and social conditions surrounding such controversial techniques. The present article's aim is to shed light on how actors in conglomerates orchestrate performance reporting manipulation practices. By focusing on how the manipulation is carried out, the article provides additional knowledge about the ways in which conglomerate executives exert control over performance indicators regarding their activities. Such an inquiry is important because it complements academic research on figure manipulation that is relevant to managers, investors, and regulators alike (Healy and Wahlen 2000).

The study uses Fligstein's theoretical framework on strategic action fields (SAFs) to demonstrate how subsidiary executives mobilize and combine a large variety of resources (e.g. their knowledge of business specificities; their understanding of other collaborators' interests; their control over local accounting calculations and procedures, etc.) to initiate cooperation within and between groups of individuals engaged in reporting figure manipulation. The article's contribution to the literature on performance manipulation is twofold. First, it demonstrates the institutional dimension of performance manipulation processes, emphasizing the group leaders' ability to implement stable rules and procedures framing other actors' attitudes regarding reporting enhancement practices. More precisely, it shows that manipulation techniques are implemented through collective and interactive processes initiated by a few actors occupying power positions and are gradually taken for 
granted by participants. Second, this study documents skills, resources, and tactics not usually associated with performance manipulation. It notably sheds light on the efforts by many group leaders to organize arenas for face-to-face discussions to maintain an intimate understanding of their stakeholders' identities and interests. Leaders can thus anticipate individuals' reactions and secure their long-term cooperation in reporting manipulation practices.

The empirical material in support of the argument consists of semi-structured interviews conducted in a French conglomerate. Performance reporting practices between a parent company and two of its subsidiaries are analyzed using data collected during meetings held with all organizational actors involved in management accounting at the interface between the sub-units.

The next section provides an overview of current literature on performance manipulation suggesting that it contributes to the institutionalization of reporting as a social field in large corporations. Section 3 introduces Fligstein's theoretical framework on "strategic action fields" (Fligstein 1997, 2001; Fligstein and McAdam 2011) and its contribution to a better understanding of the complex systems of relations in which performance manipulation takes place. Section 4 provides a description of the research method and collected material. In section 5, the general context of the case study is introduced, along with a brief description of the sub-units' activity sectors and governance peculiarities. Section 6 presents a selection of events and situations that address the research question. Section 7 discusses the major results grounded in the interpretation of empirical material, and presents the implications of the findings. The main arguments and limitations are summarized in the conclusion (section 8).

\section{Exploring the role of manipulation practices in the institutionalization of the field of reporting}

For several decades, manipulation practices have constituted an important topic for research (e.g. Beidleman 1973). Extant results focus on why manipulation happens. They specify the role of financial markets' expectations and incentive policies as important elements encouraging managers to control their performance outputs. Few studies have 
focused on actual manipulation practices. This section argues that extant research suggests that manipulation practices are structured in interactions that resemble processes of institutionalization. It calls for additional research with a holistic approach to processes ordering manipulation practices.

\subsection{Hints of the institutionalization of performance reporting manipulation practices}

It is well documented that most managers deliberately distort their financial reporting (Watts and Zimmerman 1986; DeFond and Park 1997). Since Beidleman's seminal study on earnings smoothing, it is commonly agreed that tampering with figures should only be done for the benefit of investors, in an attempt to reduce the "abnormal" variations in earnings and "to the extent allowed by sound accounting and management principles" (1973: p.653). Under such conditions, manipulations benefit the functioning of financial markets by improving earnings informativeness (Tucker and Zarowin 2006) and by allowing investors to infer the level of permanent future cash flows (Kirschenheiter and Melumad 2002). Blameless corrections that compensate for the effects of ill-timed and irrelevant events without immediate benefits for the managers are commonly referred to as earnings or profit "management."

Smoother streams of reported earnings are usually associated with stock price benefits (Goel and Thakor 2003). Not surprisingly, numerous managers of large corporations seek the benefits of reduced reporting volatility. A survey of 400 CFOs working in the USA shows that more than $95 \%$ of them prefer to communicate a smooth earnings path (Graham et al. 2005). The same study also shows that $78 \%$ of CFOs admit to sacrificing long-term performance to maintain predictability. The managers' primary objective, then, is to reduce earnings volatility whenever activities lead to discrepancies between actual earnings and expectations (Barton 2001). Reporting manipulation is thus the work of opportunistic managers interested in securing their jobs (Fudenberg and Tyrole 1995), meeting the bonus targets (Healy 1985; Dye 1988), or reducing the perception of their business risk (Gul et al. 2003). Cosmetic interventions appear to be an unanticipated side-effect of the pressure to answer calls by the hierarchy and investors (Aglietta and Reberioux 2005). Financial markets' expectations push everyone in listed companies to manipulate profits (Lambert and Sponem 2005: p.734). One extreme consequence of this is the rise of a new type of management 
accountant - "the bullshitters," in Macintosh's terminology (2006; 2009) - who are concerned only with the satisfaction of shareholders, and who excel in presenting financial statements that meet expectations. Management accounting and control systems play a major role in the diffusion of manipulation practices. The definition and diffusion of accounting indicators by upper level managers translate their will to create shareholder value (Merchant 1990; Ezzamel et al. 2008) and carry a set of values and morality that legitimize profit-seeking (Macintosh 1995). Financial incentives and promotion schemes that reward forecast accuracy and the delivery of agreed-upon outputs increase this tendency (Moses 1987). The broad diffusion of mainstream manipulation practices is known to be a symptom of the internalization of institutional legitimacy requirements (Sauder and Espeland 2009). It is assumed from extant literature that this diffusion implies the existence of institutional pressure to eliminate uncertainties from performance reporting. When the executives' aim is not to convey better quality information to external parties but rather to systematically meet their expectations, playing with performance figures is no longer referred to as earnings "management" but as "manipulation."

The question of why actors strive to control their performance indicators has attracted a lot of attention. Our understanding of how manipulations occur is not as developed. Exceptions include the detailed inquiries conducted following major accounting scandals like Enron, Worldcom or Parmalat (e.g. Gourevitch 2002) that detail the mechanisms of fraud in these contexts. The present article is not a chronicle of a massive fraud that spiraled out of control but an attempt to analyze processes related to the emergence, stabilization, and evolution of ordinary manipulation practices that are most often legal, recurrent, and of limited scale. An objective of the present research is to analyze some of the resources, tactics, and skills mobilized in providing solutions to reduce uncertainties. It will therefore focus on organizational actors, stable rules, and institutions involved in performance reporting manipulation.

\subsection{The need for holistic approaches to performance manipulation practices}

The literature has distinguished two ways of manipulating performance reporting measures. The first, "accounts manipulation," refers to decisions about accounting norms and practices with an impact on the production of reporting information such as amortization formulas, 
cut-off choices, cost calculation methods, and the opportunistic use of discretionary accruals. The second way to manipulate figures is "real profit smoothing," which encompasses all operational decisions made primarily to improve reporting indicators such as cutting R\&D expenses, deferring preventive maintenance projects, changing the agenda for major investments, and offering discounts to clients. A third type of manipulation that has attracted a lot of attention is "slack" (Cyert and March 1963), defined as a cushion of excess resources such as extra production capacity or cash reserves (Cheng and Kesner 1997). Slack is characterized by the fact that it refers to physical entities only (Sharfman et al. 1988), therefore excluding accounts manipulations as well as some real smoothing techniques such as preventive maintenance and anticipated sales. In the remaining parts of the article, we will use the expression "performance reporting manipulation" to refer to all self-beneficial techniques intended to control reporting figures.

Most articles to date focus on one type of manipulation at a time (account manipulation; real performance smoothing; slack) or specific professional populations (e.g. Board members, management accountants, salespeople). Quantitative studies, for example, tend to consider account manipulation techniques only because they grasp the phenomenon by calculating the negative correlation of a firm's change in discretionary accruals and in premanaged income ${ }^{1}$ (Kothari et al. 2005). Case-study methodologies are also subject to a restricted definition of performance manipulation techniques. An implicit distinction is often made between finance people playing with accounting standards and business people making operational decisions to look better in the reporting (see, for example, Jensen 2001). Inquiries about how organizational actors in conglomerates orchestrate performance reporting practices are thus fragmented. Yet performance reporting strategies often use the various manipulation techniques together (Merchant 1990). "Accounts" and "real" manipulation techniques are complementary solutions especially when other straightforward operational measures such as implementing leaner forms of management are not available (Ezzamel et al. 2008). There are therefore good reasons not to exclude $a$ priori any performance manipulation techniques from a study on self-beneficial performance

\footnotetext{
${ }^{1}$ Managers purportedly start from a pre-managed income series and use discretionary accruals to make the reported series smooth (Ghosh and Olsen 2009). Discretionary accruals are then calculated as the difference between reported accounting earnings and cash flow from operations (Healy and Wahlen 2000).
} 
reporting enhancement practices. By extending the scope of the population studied to both executive managers and management accountants, the present study contributes to a deeper understanding of diverse manipulation techniques potentially used simultaneously.

Management accounting for control and reporting is defined in the context of performance manipulations as a "turf for struggle and resistance" (Macintosh 1995: p.289). Macintosh shows that management accounting and control systems, far from being a mere tool in the hands of top executives obsessed with shareholder satisfaction, are also a defense mechanism for the periphery to secure breathing space between the business units and the injunctions of upper level executives (1995: p.305). No one is entirely in control of the actions of others, and profit manipulation is a key resource in the dialectic of control between top executives and operational managers (ibidem: p.308). This justifies our choice to use Fligstein's theoretical developments on "fields" to make sense of our cases. Following Bourdieu (1977), Fligstein defines "fields" as places where interactions between incumbent groups and challengers take place and where their respective positions are defined and reproduced (2001). The present article will pay extra attention to interactions taking place around management accounting exercises. We argue that reporting in conglomerates is exactly such a field, characterized by struggles between actors trying to consolidate their respective positions in a context marked by permanent attention to performance figures. The next section will introduce Fligstein's framework in more detail.

\section{Fligstein's strategic action fields applied to the actors, resources, tactics and skills of performance manipulation}

Fligstein and McAdam define "fields" as groups of social actors who interact with knowledge of one another under a set of common understandings about what is at stake and about the rules defining what actions are possible and legitimate (2011). Fligstein's framework on SAFs is specifically aimed at clarifying the conditions of fields' stability, i.e. how the stakes, the rules and the actors' positions are settled and contested in time. This approach therefore seems very appropriate for understanding how and by whom performance reporting practices, including manipulations, are enforced and modified in fields such as

\footnotetext{
${ }^{2}$ The terms "field" and "strategic action field" will be used interchangeably in the rest of the article.
} 
conglomerates, where everyone knows that reducing uncertainties regarding performance indicators is a major stake and where reporting rules are ubiquitous.

According to Fligstein, actors in fields are jockeying against each other in a game to maintain and improve their positions (2001). Most often, actors are not isolated individuals but "organized groups of actors" that "gather and frame their actions vis-à-vis one another" (Fligstein 2001: p.108). Among the actors in a field, "group leaders" are those who have proved they are able to convince others to cohere internally as a group and to accommodate other groups. Such group leaders induce cooperation in others and are said to have "social skills." The most important dimension of social skills is empathy, because it gives leaders the possibility to think "out of their mind" and to anticipate others' reactions (Fligstein and McAdam 2011).

In addition to social skills, group leaders also rely on specific resources to frame other actors' actions. Their position in the field is the most important element in the allocation of resources between actors. Existing sets of rules, hierarchies and other privileges are key resources in the hands of actors.

Finally, group leaders use their resources to design specific tactics to promote internal (intragroup) and external (inter-group) stability in relations. Fligstein identifies a long list of such tactics, all of which involve taking into account other actors' identities and interests to persuade them to cooperate $(1997 ; 2001)$. Direct authority, storytelling, brokering, mediating, and many other tactical moves are ways for group leaders to create and maintain group identities and interests, triggering cooperation and securing actors' commitment to cooperation (1997). When rules and procedures governing interactions between actors are considered taken for granted, the field becomes institutionalized.

[INSERT FIGURE 1 ABOUT HERE] 


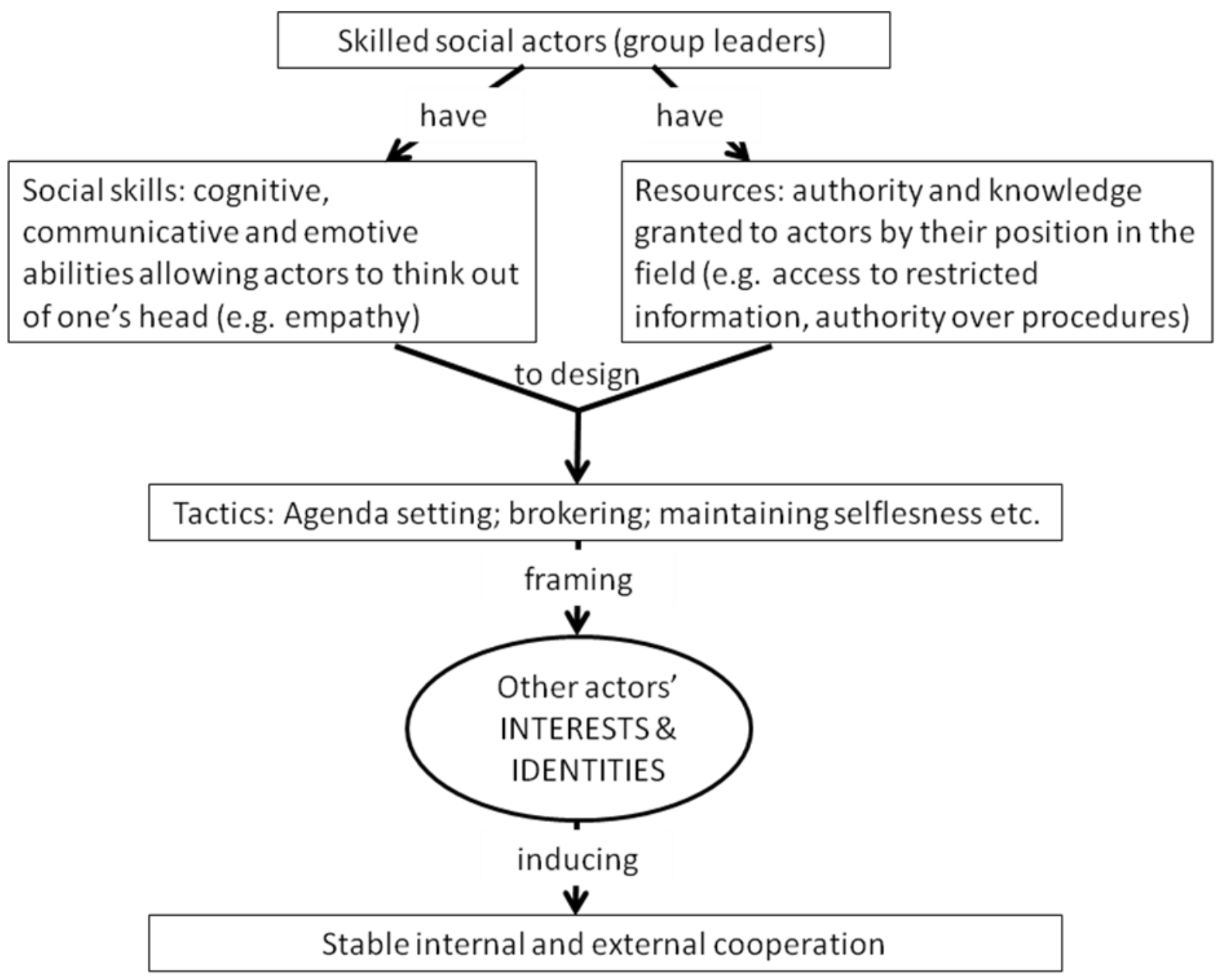

Figure 1: Theoretical framework of the process of institutionalization of cooperation (adapted from Fligstein 1997, 2001, 2011)

Institutionalization is an unfinished process (Covaleski et al. 1993). Even in the most stable of social worlds, rules, resources and preferences are not totally fixed (Fligstein and McAdam 2011). Successful leaders' positions are likely to be challenged following external shocks on adjacent fields impacting local arrangements, or due to challengers' attempts to improve their status in the field. Group leaders' tactics will differ depending on the stability of the rules governing actors' relations (Fligstein 1997). Fields can be either "unorganized" (when rules do not yet exist and emerge only from the interaction between actors); or "organized and unstable" (when rules exist but the respective positions of the various actors are being redefined); or "organized and stable but changing" (when the positions are well settled but under threat of external unexpected shock) (Fligstein and McAdam 2011). By considering situations at different stages of structuration, one can potentially gain a larger view of tactical moves in cooperation processes. 
Fligstein's framework emphasizes the role of group leaders' actions to initiate and maintain stable cooperation. It is relevant to use it to study performance manipulation practices because it provides insight into the manipulations practices' institutional and cooperative nature by answering such research questions as: "Who are the actors involved in performance reporting manipulation?" and "Where does order in manipulation practices come from (what resources, what tactics, what skills)?"

\section{Research material and method}

Eleven in-depth interviews of about 1.5 hours each directly cover the nature of the relations between the parent company and the two subsidiaries examined in this study (see Appendix 1). This sample is a selection made from a corpus of sixty-five semi-directive interviews conducted between April 2004 and May 2006 in four different conglomerates as part of a wider research project which broadly aimed to study management accounting practices as governance mechanisms in multinational corporations. All interviews were designed to document the nature of the interviewees' contributions to management accounting processes between parent companies and subsidiaries (see Appendix 2 for the interview guidelines). Questions encouraged a detailed account of recent events. Issues related to performance manipulation practices often emerged during discussions. Data analysis and conceptualization were iterative (Glaser and Strauss 1967) and the actors' deliberate attempts to control the aesthetics of their reporting gradually became an explicit focus of the data collection. From 2005 onward, additional questions aimed at collecting further details on this topic were added to the interview guide. These questions were raised when the issue had not been addressed otherwise after about an hour of discussion.

The decision to focus this paper on one conglomerate only is primarily motivated by the variety of situations observed within a single organizational setting. The relations between the holding company (Ebel ${ }^{3}$ ) and two subsidiaries (BCE and Ronelec) are particularly relevant because they illustrate situations at different hierarchical levels (a parent company and two subsidiaries) along with manipulation tactics taking place in an emerging field (between Ebel and the newly acquired firm Ronelec) as well as in well-established relationships (between Ebel and $\mathrm{BCE}$ ). This combination of perspectives provides rich material for comparing

\footnotetext{
${ }^{3}$ Ebel, like all other company names in the article, is a pseudonym.
} 
resources, tactics and skills in different local contexts while preserving a similar wider institutional environment. Taken together, the three sub-units also illustrate intra-group cooperation (within Ebel, BCE, and Ronelec) as well as inter-group relationships. Finally, focusing on one conglomerate only is also justified for the sake of brevity. However, considering the limited number of interviews mobilized, the research design can only be considered exploratory.

Eleven interviews proved sufficient to cover all major actors actively involved in performance reporting practices at the interface of the relevant business units in Ebel. Because the two subsidiaries turned out to be fully autonomous in their conduct of operations, all managers who were not involved in management accounting practices had no contact with interlocutors external to their own entity. The list of people interviewed resulted from the application of a "snowball" strategy using contact details collected during previous interviews. The first interview was obtained by contacting a personal connection working in a subsidiary. Each informant proved to have good contacts, enabling the researcher to move up the organizational chart and be introduced to people working in headquarters, other subsidiaries, and eventually other conglomerates. Within Ebel, no one described in discussions as taking an active role in performance reporting ever refused to grant the researcher an interview.

Most interviews were not recorded. Despite a strong emphasis put on anonymity during the presentation of the study to the informants, it became clear after a couple of meetings that the digital recorder had an impact on the disclosure of information about performance measure manipulation practices perceived by many as sensitive. It was therefore decided to take a less formal approach to the data collection whenever possible. Information was collected solely using extensive field notes. To reduce possible distortions, all interviews were transcribed within two days of the meetings. Comparison and contrast of actors' statements subsequently permitted the researcher to go beyond the mere accumulation of individual opinions taken at face value (Castel and Friedberg 2010) and to get a clear picture of the manipulation practices. A substantive reason for the reliance on semi-directive interviews is also to collect actors' subjective perceptions along with the technical and instrumental characteristics of reporting practices. Interviews also made it possible for 
interviewees to tackle issues covering large periods of time. Data analysis covered all accounts in which performance manipulation took place. Fligstein's theoretical framework was then used to identify the actors involved, the resources used, and the tactics employed.

\section{Research sites}

The case study focuses on the performance reporting practices within and between Ebel and two of its subsidiaries: BCE and Ronelec. Ebel is a Belgian company specializing in electricity production and distribution. In 2003, Ebel became a subsidiary owned by Panam, a French conglomerate listed on the Paris stock exchange. Ebel accounts for all of Panam's European energy activities. It is supervised by the Panam Energy Services division (PES), which oversees the energy branch worldwide. Prior to the buyout, Ebel's financial risks were somewhat limited by the diversity of its portfolio. It is only recently that Ebel started to implement a more hands-on approach following Panam's demand to concentrate on a few core businesses. Ebel has thus created new specialized divisions per sector. Tractopel, for example, is in charge of all subsidiaries concerned with the conception and supervision of major civil engineering projects ${ }^{4}$. Because the individuals involved in performance reporting between Ebel, Panam and Ebel's subsidiaries are largely the same as before, existing habits and routines condition the organization of their interactions. Nonetheless, the evolution in the capital structure has challenged Ebel representatives' position in the field. The move from the apex of the group to intermediate managers has prompted a partial renewal of manipulation practices that illustrates an organized but unstable field following the external shock triggered by Panam's acquisition of Ebel.

[INSERT FIGURE 2 ABOUT HERE]

\footnotetext{
${ }^{4}$ Tractopel Managers are the same ones as those previously in charge of the supervision of engineering activities at Ebel. Along with BCE, they also monitor two Dutch firms with expertise in locks, canals, and harbors. Other divisions within Ebel supervise electricity production companies according to the sources of energy employed (nuclear, gas, and coal).
} 


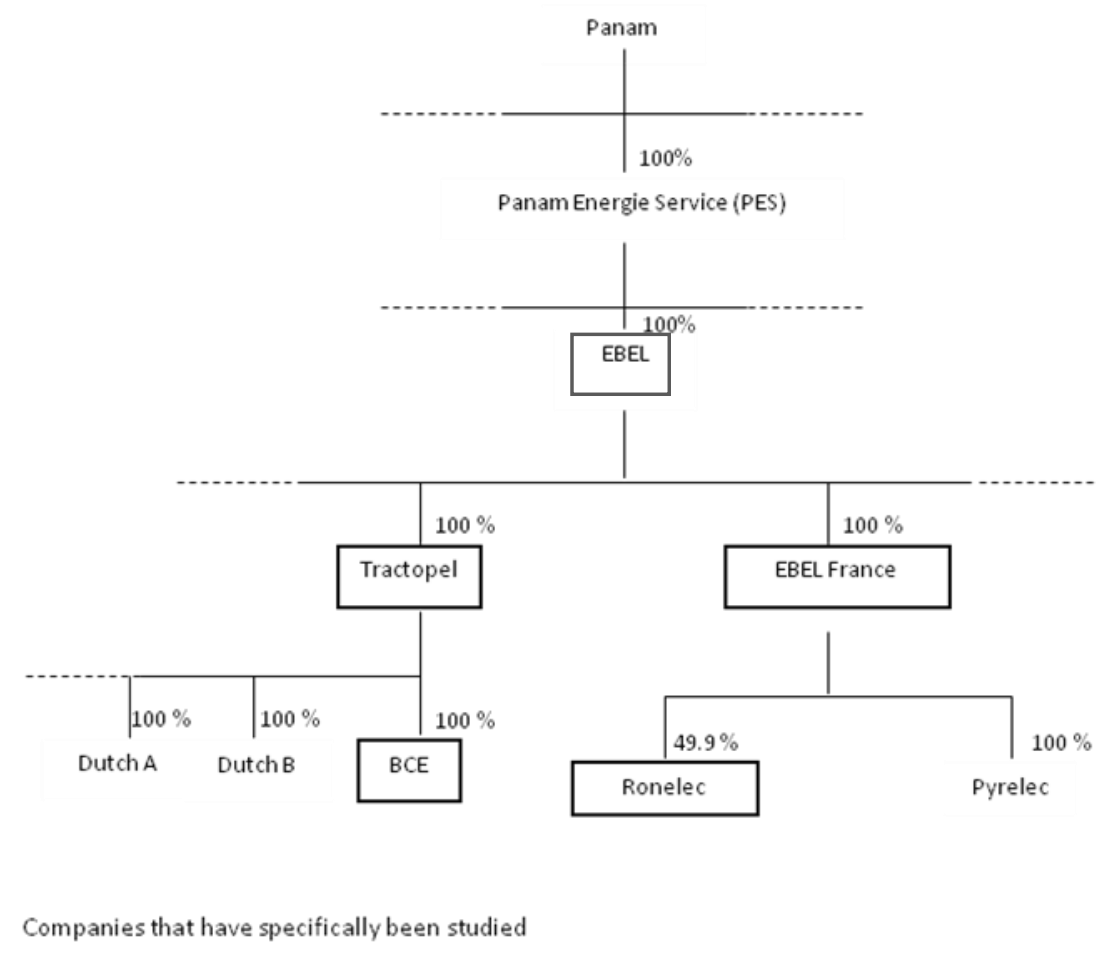

Figure 2: Simplified organizational chart of Ebel

BCE is a consulting company employing about sixty engineers with specific expertise in the design and supervision of large construction works such as river dams, nuclear power plants, high speed train lines, and large public venues (opera houses, museums, etc.). BCE has no construction assets of its own but offers assistance and guidance to contracting owners throughout the construction phases. BCE was purchased by Ebel in 1997 at a time when the company faced major financial difficulties. Competition on BCE's markets is relatively high, with key players from the USA, Canada, Korea and China responding to the same international calls for tenders. BCE has nonetheless proved to be consistently profitable since 1999. It benefits from an excellent reputation in French-speaking Africa and in Asia. It also has limited fixed overhead costs. Because the reporting relationships between BCE and Ebel have been stabilized over the past 8 years, manipulation practices within BCE are well entrenched and were considered perfectly natural to our interviewees. This situation illustrates performance reporting practices in a field that is largely organized and stable. 
Lastly, Ronelec is a former state-owned firm. It now reports to Ebel France, which gradually acquired $49.9 \%$ of the company's shares between mid-2003 and mid-2004. Ebel France is Ronelec's most important shareholder. ${ }^{5}$ Ebel nominates two of the three members of Ronelec's executive committee: the vice-CEO production and the vice-CEO finance. The third executive committee member is the CEO, who is nominated by the French "President de la République" and has almost no operating responsibilities. Ronelec's main business is running all the hydroelectric production facilities on the Rhône River. As a legacy of its past, Ronelec is also obliged to carry out missions of general interest as part of the concession contract authorizing the company to harness the river through hydro-electric power for commercial purposes. Because of this agreement, many Ronelec employees are civil servants in charge of the supervision of commercial traffic on the river and of inland-harbor facilities. Demand for Ronelec's business is growing regularly and competition is low notably because of high entrance barriers. Because it is easy to store large volumes of water in dams pending a rise in electricity prices on the spot market, margins are usually high and Ronelec is very profitable. At the time of the interviews, people at Ronelec and Ebel had been working together for less than two years and the processes that have led to the current reporting practices, including manipulative aspects, were still vividly remembered and evolving. Actions undertaken by Ebel staff when Ronelec joined the group illustrate a situation in a largely unorganized field where roles are not yet precisely distributed.

[INSERT CHART 1 ABOUT HERE]

\begin{tabular}{|l|c|c|c|}
\cline { 2 - 4 } \multicolumn{1}{c|}{} & $\begin{array}{c}\text { Ronelec \& Ebel } \\
\text { (section 6.1) }\end{array}$ & $\begin{array}{c}\text { BCE \& Ebel } \\
\text { (section 6.2) }\end{array}$ & $\begin{array}{c}\text { Ebel, PES \& BCE } \\
\text { (section 6.3) }\end{array}$ \\
\hline $\begin{array}{l}\text { Field structure } \\
\text { (cf. section 3.) }\end{array}$ & Unorganized & Organized \& stable & Organized \& unstable \\
\hline $\begin{array}{l}\text { Age of the } \\
\text { relation }\end{array}$ & Less than 2 years & About 8 years & about 2 years ${ }^{6}$ \\
\hline
\end{tabular}

Chart 1: Characterization of relations in the Ebel case

\footnotetext{
${ }^{5}$ The second largest shareholder is a state-owned investment bank that owns $20 \%$ of the company's equity and the remaining $30.1 \%$ are shared among numerous local government bodies.

${ }^{6}$ Panam acquired $100 \%$ of Ebel capital a few months before the site visits but had started to purchase large shares of Ebel capital two years earlier. It is thus impossible to precisely determine the start of the interactions between the two entities.
} 
The Ebel case provides an interesting diversity of situations covering the entire spectrum of the institutionalization levels defined by Fligstein and McAdam (2011). In addition, all companies within Panam carry out rigorous and detailed reporting processes. Consolidated accounts are produced every month for internal purposes and are communicated to external audiences every quarter. Business unit managers are very conscious of the importance of delivering satisfactory performance outputs in line with forecasts.

\section{Case study: the institutionalization process of collective performance manipulation practices in conglomerates}

This section describes resources and tactics used by conglomerate managers to reduce performance reporting uncertainties. First, the recent acquisition of Ronelec by Ebel offers an illustration of emerging reporting rules and procedures, including the birth of manipulation practices, in an unorganized field. Second, well-established routines and norms characteristic of reporting manipulation practices are analyzed through the example of the long-standing relationship between Ebel and BCE. Third, interactions that challenge stable existing agreements and practices that are taken for granted are studied through the external shock triggered by Panam's buyout of Ebel.

\subsection{Ordering performance manipulation practices in emerging fields: framing the context for manipulation}

The integration of a new company into a conglomerate requires the implementation of rules governing interactions with the subsidiary. In this section, it is argued that the managers' ability to tactfully use the resources granted by their positions, such as authority over information systems and HR policies, supports the ordering of performance reporting practices in newly acquired entities. Notably, tactics such as nominating executives with prior work experience at headquarters and setting up discussion arenas on performance reporting procedures are shown to be powerful means to initiate cooperation around manipulation techniques.

6.1.1. Diffusing the anxiety of performance uncertainty: appointments to distribute interests Ebel has entrusted two vice-CEOs with prior work experience at Ebel headquarters with the mission of reorganizing financial procedures and production operations at Ronelec. Within 
the first few months of the buyout, the vice-CEO in charge of operations implemented a centralized command center similar to those running gas power plants owned by Ebel. Production sites all along the river are now managed from a trading room by newly hired finance managers in control of the waterworks channeling the water to the alternators. The on-site technicians no longer take part in production operations.

"We have implemented a command center in Lyon that supervises the 18 production centers [...] Local people are still needed mostly because we do not have automated control in case of flood." (Vice-CEO Finance, Ronelec)

Since the buy-out, economic rationalization and spending cuts have also resulted in a dramatic change in Ronelec's culture. Reporting measures and corporate discourses are diffusing new values and priorities in the company.

"We taught everyone how to keep track of their expenses [...] Our profits have gone from $€ 20$ to 100 million within two years. This is mainly due to savings related to cost control procedures. Operating expenses used to increase by $15 \%$ a year; we put an upper limit at $2 \%$ a year." (Vice-CEO Finance, Ronelec)

The emphasis put on leaner forms of management is explicitly supported by Ebel's policies, which include financial rewards for Ronelec top management indexed to indicators such as EBIT, operating margin, and Free Cash Flows.

At first, only the newly appointed vice-CEOs fully endorsed the parent company's ethos. The rapid shift in corporate culture was relayed by the recruitment of managers well accustomed to conglomerates' usual concerns. An early decision by the new management team was to hire a CFO with prior experience in public firms and audit companies. His mission was notably to abide by stringent closing deadlines so that Ronelec could rapidly fit into the conglomerate's consolidated reporting.

"Being part of Ebel dramatically changed deadline management. Before that, [Ronelec] had to close its accounts on April 15 just in time to pay income tax. From one day to the next, I was told to have it ready for January 12." (CFO, Ronelec)

Ronelec vice-presidents also paid attention to re-organizing the partitioning of the company's activities with a clear distinction between departments with a profit-oriented culture (production; sales; finance) and other units in charge of public services (such as navigation on the river and management of harbor facilities), where a majority of Ronelec 
employees with civil servant status work. ${ }^{7}$ Objectives of listed corporations have rapidly been accepted by the new recruits and ignored elsewhere. Indeed, initial resistance movements and the few strikes that had occurred when the decision to privatize the company was announced in 2002 have not resumed. Ebel and Ronelec executives have succeeded in securing groups of workers sympathetic to the requirements of for-profit organizations at core positions.

All subsidiaries within Ebel share similar constraints about the reporting deadlines and formats. Ronelec had to quickly endorse the detailed financial templates promoted by the group. Reporting documents at Ebel are designed for gas and nuclear power plants, which had accounted for the company's entire electric production capacities prior to the purchase of Ronelec. One of Ebel's important KPI (key performance indicators) is the financial contribution per MWh, which is calculated as the difference between the selling price of 1 $\mathrm{MWh}$ and its production cost. Yet production cost is hardly relevant for Ronelec, which is primarily dependent on free-of-charge rainwater for its activities. To abide by Ebel's standards while meeting its operational informational needs, Ronelec managers run two sets of reporting figures that are targeted at different audiences.

"We [Ronelec] explained to them [Ebel] that we were really keen on taking into account all the data they required, that we would report to them all the data they expect, but that we would not use them or refer to them at our level because it would mean nothing much to us. We thus pass on the information every month according to their financial aggregates but we base our analyses on our own data." (CFO, Ronelec)

Managers involved in the reporting are conscious that they belong to an overarching entity with strict reporting principles (deadlines, formats, indicators etc.) to which they must adapt. They quickly learn how de-coupling techniques can help them cope with hierarchical demands while preserving data that is useful for operational purposes. They thus combine lean management reforms and de-coupled reporting practices.

The conglomerate's expectation for homogenized and reliable forecasts is the driving force behind the efforts of Ronelec executives to find efficient solutions, even those that are unorthodox, to meet expectations. Authority over HR decisions is an important resource for both the parent company managers and the subsidiary executives. Ebel managers have

\footnotetext{
${ }^{7}$ All new employees are now hired under private contracts.
} 
transformed Ronelec into a reliable contributor to the conglomerate's consolidated reporting by appointing new managers who endorse Ebel's objectives and interests. Ronelec vice-CEOs also relied on nominations to bring in supporters with interests and identities well aligned with the conglomerates' concerns while isolating difficult outliers. Therefore, a specific skill for leaders willing to induce cooperation in others is to identify people who are likely to cooperate and those who should be isolated (Fligstein 1997). Ebel and Ronelec executives gradually transformed the former State-owned company into a subsidiary eager to find solutions to deliver satisfactory performance outputs.

\subsubsection{Legitimizing new manipulation practices: the implementation of arenas of cooperation}

Despite soaring profits, Ronelec executives are still required, like all other management teams within PES, to keep variances between budgeted figures and actual outputs to a minimum. The estimation of future results has always been considered an impossible challenge for people working at Ronelec. Rainfall for the year is unpredictable and it is the decisive factor needed to estimate hydroelectric production capacities. The finance department at Ronelec is diligent in producing state-of-the-art forecasts, the precision of which is invariably low.

"The forecasts are based on an average rainfall calculated over the last forty years. It turned out that last year was the driest ever ..." (CFO, Ronelec)

To explain the volatility of their performances, Ronelec managers transmit extra information regarding local specificities that affect production. By commenting on rainfall and legal regulations, Ronelec financial managers have, for example, effectively conveyed their company's business specificities to upper levels. A management accountant at Ebel France easily explained why hydroelectric production levels are intrinsically uncertain.

"Ronelec is very specific. Their production capacity depends on the weather report. [...] Not only do they generate power depending on the river flow but in addition they cannot do what they want with the water available. They sometimes have to release part of it for environmental or other reasons" (Management accountant, Ebel France)

Yet managers at Ebel France have proved reluctant to compromise about reporting formats and objectives. The shared understanding of why Ronelec cannot produce reliable forecasts does not eclipse the primary requirements of PES reporting: accurate performance predictions. Although upper managerial levels know why Ronelec's performance is 
structurally uncertain, they remain unyielding and do not mitigate their expectations. Ebel's attitude strongly encourages the search for local solutions to cope with their demands.

A ground-breaking solution that reduces performance uncertainties considerably came from a new approach to maintenance activities initiated by Ronelec's finance department. Whereas production capacities are unpredictable, maintenance costs are both highly foreseeable and flexible. The investments on dams built about fifty years ago are now almost entirely depreciated, and current expenses are mainly related to the maintenance of existing facilities. It is only recently that it has become common practice to postpone or anticipate maintenance projects for the sake of performance manipulation. If the current year appears to be particularly rainy and profitable, a few maintenance projects scheduled for the following year are brought forward. Alternatively, some of the maintenance projects may be postponed to compensate for a drought or low selling prices. In short, it has become possible for Ronelec executives to control financial figures regardless of the weather! This manipulation technique does not impact Ronelec's long-term performance but spreads it out conveniently over time.

"We [Ronelec] have the option of not doing anything about maintenance for a year and we should then save between $€ 20$ and 30 million without impacting our production capacities at all."“(CFO, Ronelec)

Unsurprisingly, establishing maintenance schedules has become a point of contention between financial experts and engineers in charge of safety and production. Agreements are reached during quarterly meetings where managers voice their arguments in favor of safety policies or performance objectives. Maintenance people call the meetings "the axe committee" in reference to the budget cuts announced there. The finance department leads in discussions but compromises are nonetheless reached despite disparities in participant's priorities.

"I attend the 'axe committee'... It is where budgets are revised as far as expenses are concerned. We [Ronelec top management] see together what is conceivable to do for the coming year" (Vice-CEO Production, Ronelec)

Ronelec vice-CEOS have institutionalized a new arena where they insist that their preoccupations be prioritized, but where decisions are validated collectively. Although the vice-presidents exert a hierarchical authority on the maintenance department, Ronelec executives sometimes mitigate their opinions according to the feedback from the other 
group members on whom they are dependent. For example, the $2 \%$ threshold imposed on growth in operating expenses (cf. quote section 6.1.1), including maintenance, has been increased to $5 \%$ following the acknowledgement by the vice-CEO in charge of finance that he "had gone too far" (quote). Ronelec vice CEOs thus endeavor to avoid alienating their contact, specifically by taking their opinions into account.

The axe committee is a local institution where tensions between contradictory objectives such as profitability and security can be addressed on a regular basis. In the end, Ronelec vice-CEOs have managed to introduce rules and committees that have stabilized their relations vis-à-vis the maintenance people and have put the conditions to satisfy Ebel's expectations in place. Solutions to reduce performance uncertainties are not straightforward; they require time and inventiveness.

In a context where Ebel managers' impose performance targets on the periphery and deliberately ignore operational explanations referring to local specificities, Ronelec leaders are very concerned with finding innovative local solutions to compensate for business uncertainties. These solutions emerge during episodes of contention, which are transitory steps (Fligstein and McAdam 2011). Local executives adapt their solutions to upper level pressure and local contingencies, making the most of business opportunities at hand and possible cooperation. They do not duplicate manipulation practices known from prior experience but devise local arrangements. Figure 3 shows that Ronelec vice-CEOs' tactics combine resources granted by their top managerial positions (e.g. control over IS, reporting, HR policies) with specific knowledge about their interlocutors' stakes and expectations. These tactics primarily aim at framing sub-groups with radically different cultures and identities (such as maintenance and finance departments) along with institutions to help them find reasonable arrangements about performance reporting. Thus, the decision to implement regular "axe committee" meetings induces the existence of an arena where real performance manipulation practices become stable and collective solutions to reduce uncertainties.

[INSERT FIGURE 3 ABOUT HERE] 


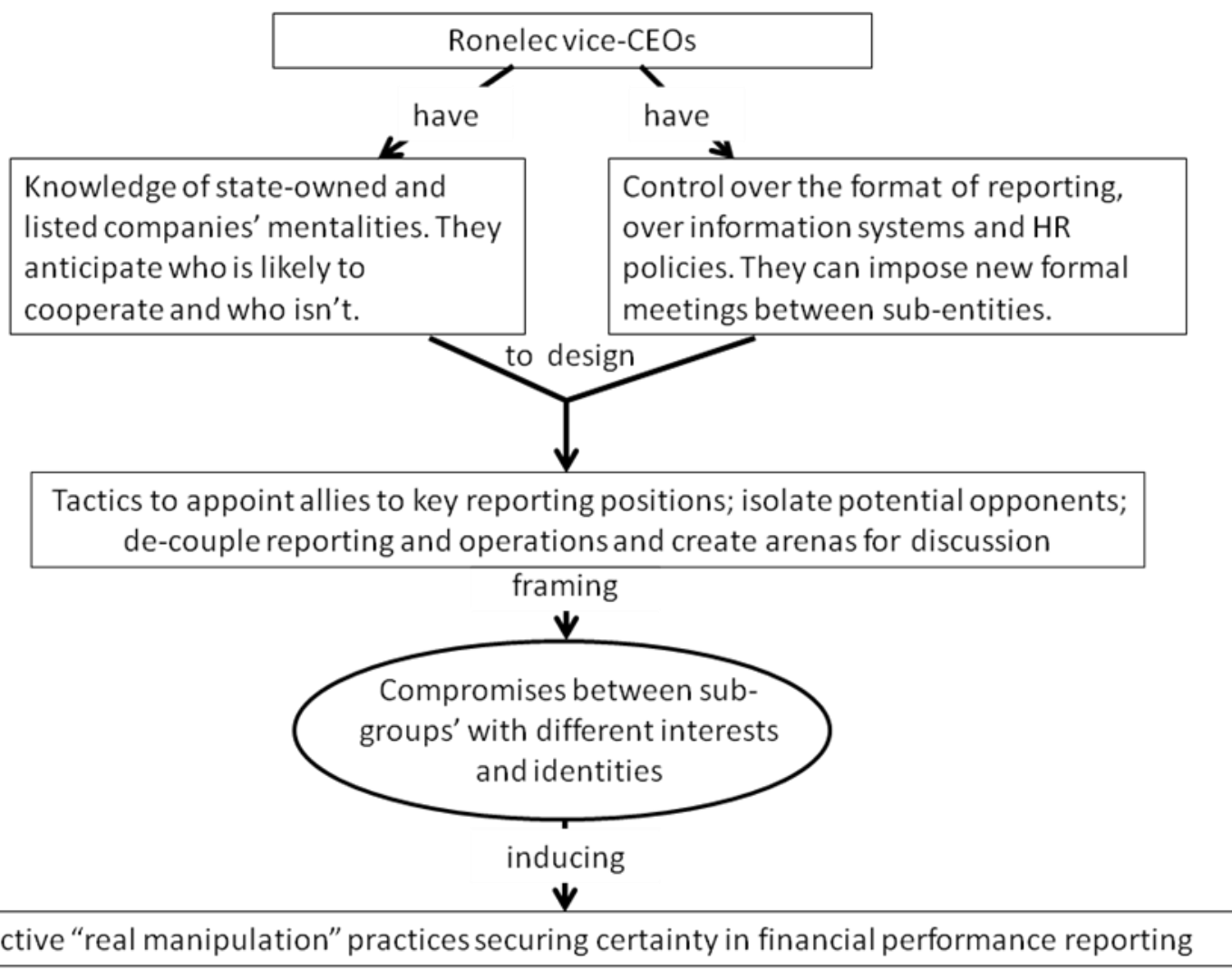

Collective "real manipulation" practices securing certainty in financial performance reporting

Figure 3: Ordering performance manipulation practices in an unorganized field (the case of Ronelec)

Upper levels expectations are met making decisions encouraged by financial concerns but also validated by maintenance people. Once Ronelec has achieved a form of consensus about the means and institutions to control its performance reporting, there is a new sense of order and certainty in relations between Ronelec and Ebel.

\subsection{Routines of collective performance manipulation: organizing certainty in Ebel}

The following sub-section discusses how BCE executives maintain control over the company's financial reporting through recurrent manipulation practices involving groups of actors. Tactics to monitor performance reporting communication include taking advantage of the mosaic of IS to monitor reporting timing and figures as well as the centralization of the uses of peripheral financial resources via the creation of a collective feeling of shared identity among BCE employees. In both cases, BCE executives' position in the field, at the interface between operational experts and managers of the parent company, is crucial to bridge the gap between upper level expectations and business operations.

6.2.1. Influencing expectations: the control of IS content by the executive committee 
Resources initially mobilized by Ebel eight years ago to integrate BCE into the conglomerate were very similar to those described in the previous section regarding Ronelec. BCE's first CFO was appointed by Ebel immediately after the buy-out in 1997. He had previous experience in the parent company and designed most of the management accounting tools still in use at BCE. The first CFO of the Ebel era insisted on implementing and improving performance indicators based on the number of hours billed to clients, and he put strong emphasis on the follow-up of costs through the use of detailed and regular reporting for each contract. In addition, part of his mission was to find ways to reduce BCE's performance volatility due to the company's high exposure to exchange rates, the constant use of innovative construction techniques, and the numerous projects carried out in unstable foreign markets. Using his knowledge of accounting techniques and the opportunities offered by specificities of the business, the CFO trained BCE executives to better control the company's figures using accounting accruals to compensate for unexpected events.

"They [Ebel] sent us someone for two years to implement the reporting. He knew the engineering business well from his past experiences. [...] He introduced more formal and more rigorous procedures. [...] Before him, it was rather amateurish. [...] As far as business hazards are concerned, he designed the use of accruals in relation to the projects" (Vice-CEO, BCE)

Excess profits are temporarily set aside in the form of accruals initially justified to cover bad debts or exchange rate volatility. Confidence in the company's ability to deliver expected level of output is increased by the use of financial reserves accumulated as part of discretionary risk policies.

"It is very easy to meet the objectives when we are profitable because it is always easy not to report profits by keeping them aside to cope with some sort of risk analysis or another." (Vice-CEO, BCE)

"A basic principle is to implement 'the squirrel' policy and to put enough hazelnuts aside to bring them out when we need them. In our business, when we come up with very regular and very predictable profits, it does not mean that the business is stable at all. It simply means that we manage to compensate downturns using financial reserves. People who deny this are liars." (CEO, BCE)

BCE's attention to shareholders' expectations and to profitability was achieved sustainably by the year 2000 , with the successful implementation of reporting documents and procedures. These habits are remembered and are still very popular among BCE's top executives. 
Because the CFO was nominated by Ebel and then reintegrated into another one of the conglomerate's companies, there are reasons to believe that, for many years, Ebel managers have known about BCE's methods for delivering highly reliable performances. Yet the precision achieved using performance manipulations suits Ebel managers, who are relieved that they would not be learning about unexpected events at the last minute. Indeed, BCE's expertise in manipulation techniques does not run counter to Ebel's interests. Both BCE executives and Tractopel managers welcome the serenity that comes with confidence in future performance.

Additional sources of financial leeway have since then developed and had become routine by the time of the interviews. Despite the use of accruals, budgetary previsions over twelve months cannot be guaranteed because of potential unexpected events with impacts beyond the capacities of financial reserves. Additional manipulation techniques have been implemented over time and include the monthly control of the timing and content of the flow of data sent to Ebel. For six months each year, BCE executives postpone the communication of actual data and artificially align their reporting figures with the budgeted ones.

"It is really only when the sky falls down on to our heads [that Ebel gets actual figures]. Ebel usually receives until mid-year a monthly balance sheet and a financial reporting that are very mechanical and correspond more or less to the budget. In June, we examine the situation in detail with all project managers to know if the trend is to be modified or not." (Vice-CEO, BCE)

BCE is running its own information system distinct from the ERP in the parent company. Group controllers cannot gain direct access to BCE's databases. The transmission of information to the upper level is therefore mediated by BCE executives who fill-in reporting templates, keeping the upper hand on declared performances without having to be consistent with internal reporting data. BCE executives are in a position to decide on the degree of completion of, and therefore the costs and revenues associated with, the various current construction projects. Holding back unexpected gains and losses from official reports masks "surprises." Because BCE's reporting does not reflect the volatility of operations, BCE executives do not create unreasonable expectations when the beginning of the year is generous, and they limit Ebel's apprehension when the performance of the first few months is poor. It is therefore only in June - when the year's performance is easier to ascertain by 
considering actual figures and potential reserves available- that decisions are made regarding the opportunity to communicate eventual changes to the year-end estimations. BCE executives know that this is the latest time in the year that they can modify Ebel's initial budgeted expectations regarding end-of-year's outputs.

"[In June] we list bad news, if any, to be announced to the shareholders. It is still acceptable to announce problems in June. The shareholders loathe disasters in September. In September, we see about the profit which will be made in December." (Vice-CEO, BCE)

BCE managers have a monopoly on official communication with Ebel. A central skill for them is knowing when to postpone the announcement of important difficulties, when to compensate for them using reserves, and when to communicate overtly about them. Stakes are high; BCE executives are very conscious that they must weigh the possible consequences of their choices regarding performance communication decisions.

"It is dangerous because the hierarchy [Ebel] does not necessarily see the real problems or then it sees them too late." (CFO, BCE)

On the strength of their knowledge of their activities, and with their good command of internal information systems and accounting processes, BCE executives handle the timing and content of information sent to upper levels. The same reporting practices unfold following similar processes every year. Manipulation practices abide by established routines and procedures.

\subsubsection{Centralizing the use of individuals' reserves: the construction of group identities}

In addition to the leeway offered by accruals management at HQ level, BCE engineers in the periphery also contribute to manipulation practices. Each contract is monitored from a financial perspective by the engineer in charge of supervising the construction process. For projects situated in distant countries and with lifespans covering several years, the engineer is responsible for assessing achievements and expenses to date, but is not required to ensure traceability through written digital records. Evidence of the financial reserves constituted at this organizational level was gathered during an interview when, to illustrate a point, the CFO opened a drawer and withdrew randomly follow-up documents related to current contracts. He then faced some scribbling in pencil on one of the documents, which he said indicated that, in this case, a little less than $€ 100,000$ were "unexpected other nonbudgeted charges." The CFO then explained that it was common to anticipate costs, to 
maintain projects at a "normal" profitability ratio. A particularly well sold contract can thus be an opportunity for the project leader to cover excess charges to compensate for future possible deviations of expenses. The financial leeway may be used to counterbalance poor performance either of the project in question or of another contract.

Such reserves are absent from BCE's information systems. Central management cannot follow-up the "nest-egg" systematically. The amount and availability of the savings accumulated in the periphery are nevertheless not kept entirely secret. Information about them is shared during meetings attended by top executives and business-unit managers. BCE leaders organize gatherings of employees from BCE's various business units, where resources for manipulation are inventoried on a regular basis. BCE executives may not have full control over local cushions, but they manage to mobilize part of these resources for the benefit of the company as a whole.

"Earning management is done at the headquarters because it is the only place where we know and can appreciate what can be told [to Ebel]. Every unit makes its index of risks with a mass of money put in reserve. We then manage the financial reserves collectively according to our profit objectives and according to the plausibility of the figures related to using a reserve in a given country or not." (CEO, BCE)

Decisions regarding the soundness of using local reserves are made by BCE top executives, who are the only ones in a position to judge what adjustments are reasonable, both from a financial and an operational perspective. BCE leaders need good contacts with operations, control over communication channels, and knowledge of the expectations of upper managerial levels to deliver a satisfactory level of output. We will now see that cooperation from engineers also relies on the construction of a group (BCE engineers) made up of members defending interests and sharing an identity distinct from those of another group: the managers of the parent company.

All current executive positions in BCE are held by engineers with a long career in the company. Both the CEO and vice-CEO have more than twenty years' seniority in BCE. They share operational data reluctantly with the parent company, and both feel that nothing should be done to encourage Ebel to get involved in technical issues.

"I am a rather disciplined man. I always answer yes to requests [from the parent company]. However, when the purpose is to report information not for the sake of account consolidation but with the idea of turning BCE into a mere division managed from the upper level, then, we [leaders of $\mathrm{BCE}$ ] become very, very prickly. [...] Collecting data to 
transfer it above so that they [managers of Ebel] come up with erroneous conclusions from it? No!" (CEO, BCE)

Earnings manipulation is advocated as a necessary move to support BCE's long-term viability and autonomy. It is the CEO's opinion that, without it, not only would "[Ebel] siphon off everything," but it would also put the company at risk. The reporting manipulation policy is overtly endorsed by BCE executives, who claim that it is important to preserve technical expertise and an engineering culture to ensure BCE's credibility and longevity. Smoothing things over is said to provide the means to meet the minimum financial performance requirements needed to keep Ebel managers (as opposed to BCE engineers) at a distance. The cohesion between engineers is further supported by policies that favor collective targets. For example, no one in BCE has a variable compensation package based on individual performance indicators.

"We prefer to have a collective target for the incentives. [...] I am convinced that individual performance objectives lead to competition, to conflicts between people who don't talk to each other anymore." (CEO, BCE)

Measures are taken to convince BCE engineers that their effort to raise the company's performances up to the parent company's expectations is for the benefit of the subsidiary, not for financial excellence for its own sake. For example, all members of the BCE executive committee share information about their remuneration package with the unions' representatives, and they are proud that their bonuses are not based on financial objectives.

Figure 4 shows that it is BCE executives' knowledge of their interlocutors' values and expectations combined with their hierarchical prerogatives that allow them to take on the role of key interface between radically different organizational sub-entities. BCE executives' authority over reporting IS and remuneration policies, as well as their knowledge of engineers' values and shareholders' expectations, are instrumental to claim that they take charge of the subsidiary's destiny on behalf of those opposed to "Brussels clowns" and "shareholders with short-term appetites," as they dub Ebel's managers. BCE leaders promote a culture of engineering distinct from Ebel's managerialism and create a sense of shared destiny among BCE engineers.

[INSERT FIGURE 4 ABOUT HERE] 


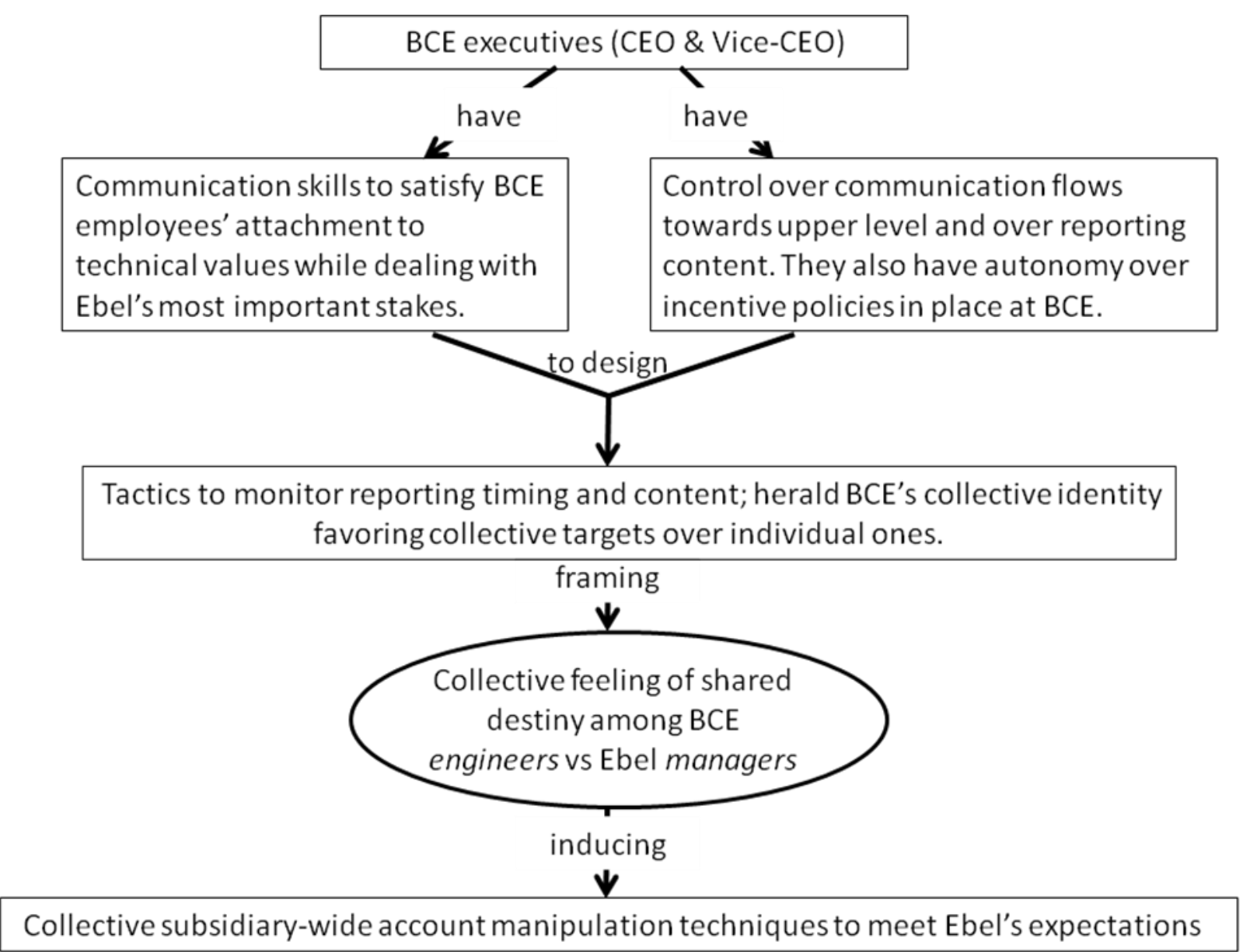

Figure 4: Perpetuating performance manipulation techniques in an organized and stable field (the case of BCE)

BCE leaders situate themselves as spokespersons of a community of highly competent technicians over which they have influence and from which they draw resources for manipulation. They satisfy upper level's reporting expectations via collective account manipulation practices framed as an essential component of the defence of the subsidiary's identity and autonomy. The tension with the parent company offers them the opportunity to orchestrate on a regular basis the collective use of financial buffers created by engineers who have identities and interests they know very well, and that they have helped shape through their discourse and management.

\subsection{The dynamics of the status quo}

This section illustrates the incidental effects that changes in Ebel's capital have on performance reporting processes between the company, Panam and BCE. It illustrates Ebel managers' attempts to modify stabilized forms of manipulations and BCE's reactions involving new practices in favor of the status quo. This section illustrates the dynamics of 
interactions in the evolution of temporarily destabilized organized fields through the buyout of Ebel by Panam. First, Ebel managers convince BCE executives to contribute to new reporting procedures following Ebel's repositioning from a diversified parent company to one at an intermediary managerial level. Second, we consider an example of a manipulation practice at BCE Headquarters that minimizes Ebel's intrusion into operations management.

\subsubsection{De-coupling reporting and operations: divergent decisions despite centralized authority}

Following its recent acquisition of Ebel, Panam decided that the new branch would no longer pursue its own conglomerate strategy, ${ }^{8}$ but would concentrate on the management of a few core businesses. For example, at the time of the study, Ebel was required to sell two subsidiaries that did not fit PES' strategy: a German dockyard thought to be financially risky, and a French high-tech firm that was not part of priority markets. Deprived of what used to be the core of its managerial contribution, Ebel has nonetheless kept control over its organizational structure. In particular, it has created new layers of management dedicated to specific business sectors. New divisions like Tractopel advocate for greater interventionism in management.

"Now there is a very remarkable evolution [in the reporting]. We want to know what is causing the impacts and variations. We realize that the information we could access before was not detailed enough and we now are stepping up the control of subsidiaries." (Management accountant, Tractopel)

Personnel at Ebel summarize PES' strategic intent as aiming for rapid growth on core activities while limiting financial exposure. The creation of Tractopel, with the explicit mission of "making sure that the activities of subsidiaries stick to the strategy of the group," (Tractopel CEO) exemplifies Ebel managers' desire to contribute to the corporation's new strategic missions. Indeed, Tractopel managers have also introduced additional control mechanisms to monitor financial risks in relation to investment decisions. The Risk Assessment Forms (RAFs) are designed to provide an appointed committee of parent company representatives with information on major projects carried out in the division. RAFs are completed by subsidiary executives and contain details about the project's location, the client, and a summary of financial implications both in terms of risks and opportunities.

\footnotetext{
${ }^{8}$ A conglomerate's strategy is characterized by Roberts as "a small corporate group focused on acquisitions and financial and strategic control of existing business, whilst operating units are left with responsibility for running their business" (1990: p.108).
} 
All BCE contracts exceed the $€ 2$-million threshold, above which RAFs must be validated. RAFs generate documents, meetings, and statements in conformity with acknowledged standards of rationality applied to decision-making. Tractopel managers thus equip their relations with BCE executives in a way that satisfies their new hierarchy. These reforms are undertaken with the support of former Panam executives recently nominated at the head of PES and Ebel's finance departments. The RAF procedure duplicates what Ebel experiences in its relations with PES to the extent that it is part of PES' strategy to make sure that no decision involving potential financial risks can be made without prior validation from the upper level.

"Before [the buy-out], we [engineering people within Ebel] used to communicate information about new projects when the deals were signed but this is all over now. No one does it anymore and we [Tractopel] ask our subsidiaries not to do it as well." (Management accountant, Tractopel)

Yet decisions taken by Ebel are not irrevocable. Ebel executives are glad to revise their "no go" decisions according to the reaction of the subsidiary. Both the deputy director and the CEO of BCE confirm that the parent company's positions are regularly challenged:

"And then, one day, we learn that finally we should not respond [to the bid]. That's typically the glory of the 'Mister no go.' They do not give a damn about the time we lost because of their whims! [...] [To pursue the project] it is then enough to make a fuss and yell 'you are pulling our leg, aren't you? You must be kidding! You will have all of us blacklisted,' etc." (CEO, BCE)

"There has never been definitive opposition from Ebel. Their risk analyses are based on forms only. They [Ebel] are not ready to make the final decision. If the affair really is rotten, we know it too and so we make the decision way before and we do not refer it to Ebel for arbitration." (Vice-CEO, BCE)

In the end, the operational expertise of business people prevails. Tractopel managers hear the cause of BCE and allow the subsidiary to proceed according to its own judgment of the situation.

The gap between formal decision-making procedures and actual decisions exemplifies a well known situation of loose-coupling (Meyer and Rowan 1977). The gathering and analysis of vast amounts of information about peripheral operations reflects accepted norms of risk management but has no effect on the actual sequence of events at BCE. Tractopel takes on characteristics of a "decision oriented organization," happy to raise possibly negative uncertainties to demonstrate the quality of its job (Brunsson 1989) while not producing outcomes other than a paper trail (Ezzamel et al. 2007). By enforcing RAF procedures, 
Tractopel managers' legitimacy is strengthened because of its visible efforts in defense of the conglomerate's strategy. Yet managers in Tractopel use their authority over management accounting procedures with tact, such that the company can preserve the subsidiary's autonomy on operational issues. Not insisting that central decisions be taken into account is a necessary condition to encourage BCE executives' participation in the RAFs procedures without hindering their capacity to consistently deliver expected levels of performance.

The Tractopel-BCE case of de-coupling is original because it is generally expected that formal 'decisions' are ex-post endorsements for options decided elsewhere (Brunsson 1989: p.387), whereas in this situation two distinct strands of authority (hierarchical and operational expertise) end up having contradictory conclusions. The fact that operational projects may proceed despite formal opposition from Ebel illustrates Tractopel managers' social skills. Indeed, granting BCE executives the final word about future projects reinforces their commitment to delivering satisfactory profit levels. BCE executives may ignore Ebel's decisions only to the extent that it helps them produce positive economic outputs. While upper level management concentrates on the administration of procedures such as RAFs, the responsibility for delivering the expected level of performance each year lies in the periphery.

\subsubsection{Negotiating over reporting innovations: manipulations to remind others of their} interests

BCE's contribution to Ebel's consolidated profits predominates in the subsidiary's performance evaluation. Ebel's attention to financial outputs provides BCE executives with relevant arguments to defend their autonomy. For example, they tend to overemphasize the counterproductive effects of tighter control procedures when under threat of upper level interventionism. BCE's official discourse on the cost of extra monitoring procedures, like RAFs, is that "the reporting keeps two to three employees busy full-time" (BCE CEO), while other sources evoke lower figures.

"Our position is to say that the reporting costs us at least two full-time employees when in fact it is more like one and a half." (Vice-CEO, BCE) 
This discrepancy is a deliberate attempt to signal the potential negative impacts that additional control requirements would have on profitability. By extending the scope of reporting to the cost of reporting itself, and by exaggerating this cost, BCE executives convey that any additional reporting procedures would necessarily impact consolidated profits. Ebel's interlocutors are thus required to find a balance between their desire to implement further reporting requirements and the necessity to safeguard the conditions to collect high levels of profits from the subsidiary. BCE executives limit further increases in reporting demands by providing their interlocutors at Ebel with information signaling that it is in their interest not to implement additional control mechanisms.

BCE leaders' communication relies on their position at the interface with the parent company. They know what matters to their contacts and can comment on the reporting content. This allows them to devise a tactic of expanding the scope of reporting with indicators not explicitly required by the upper level but which retain people's attention at Ebel because they raise issues of vital importance to them. BCE provides data designed to let people in the parent company decide for themselves while knowing that their conclusions will be favorable to BCE's interests. This example illustrates the communicative dimension of BCE executives' social skills in that they provide their contacts with the information they need to reach the conclusion that best suits the periphery. BCE executives remind these stakeholders that they have a common interest in keeping reporting costs as low as possible. BCE executives also prove skilful in organizing themselves. Control over performance outputs seldom lies entirely in the hands of a single organizational actor (Macintosh 1995). Even the simplest reporting manipulation techniques, such as over-emphasizing the cost of control exerted by the parent company over its subsidiaries, requires that all subsidiaries' executives in contact with upper management levels are consistent in their exaggerations. BCE's CEO, vice-CEO, and CFO argue that keeping the reporting to a minimum is a necessary condition to preserve Ebel's ability to deliver timely and reliable performances, and collectively agree that overvaluing the cost of reporting is appropriate.

Figure 5 argues that Tractopel executives as well are skilful managers to the extent that they press for more reporting efforts but also ponder over "what is possible and impossible" from the other actors' perspectives (Fligstein 1997). They pay attention not to use their resources 
in a way that would alienate BCE leaders' commitment to existing satisfactory operational and manipulation practices. In the RAFs example, Tractopel managers demand at minimum that BCE executives fill in the reporting templates but do not impose their decisions on operations. Because they keep listening to information from the periphery, they are aware, and often reminded by BCE executives, that state-of-the-art reporting procedures should not be pursued to the detriment of the subsidiary's ability to deliver good economic performance. Tactics such as offering the possibility to de-couple reporting and operations encourage BCE leaders to compromise with the hierarchy about practices that are worth preserving and new procedures which are acceptable. Finally, leaders of the parent company and of the subsidiary interact and jointly define the conditions for cooperation regarding performance reporting manipulations.

[INSERT FIGURE 5 ABOUT HERE]

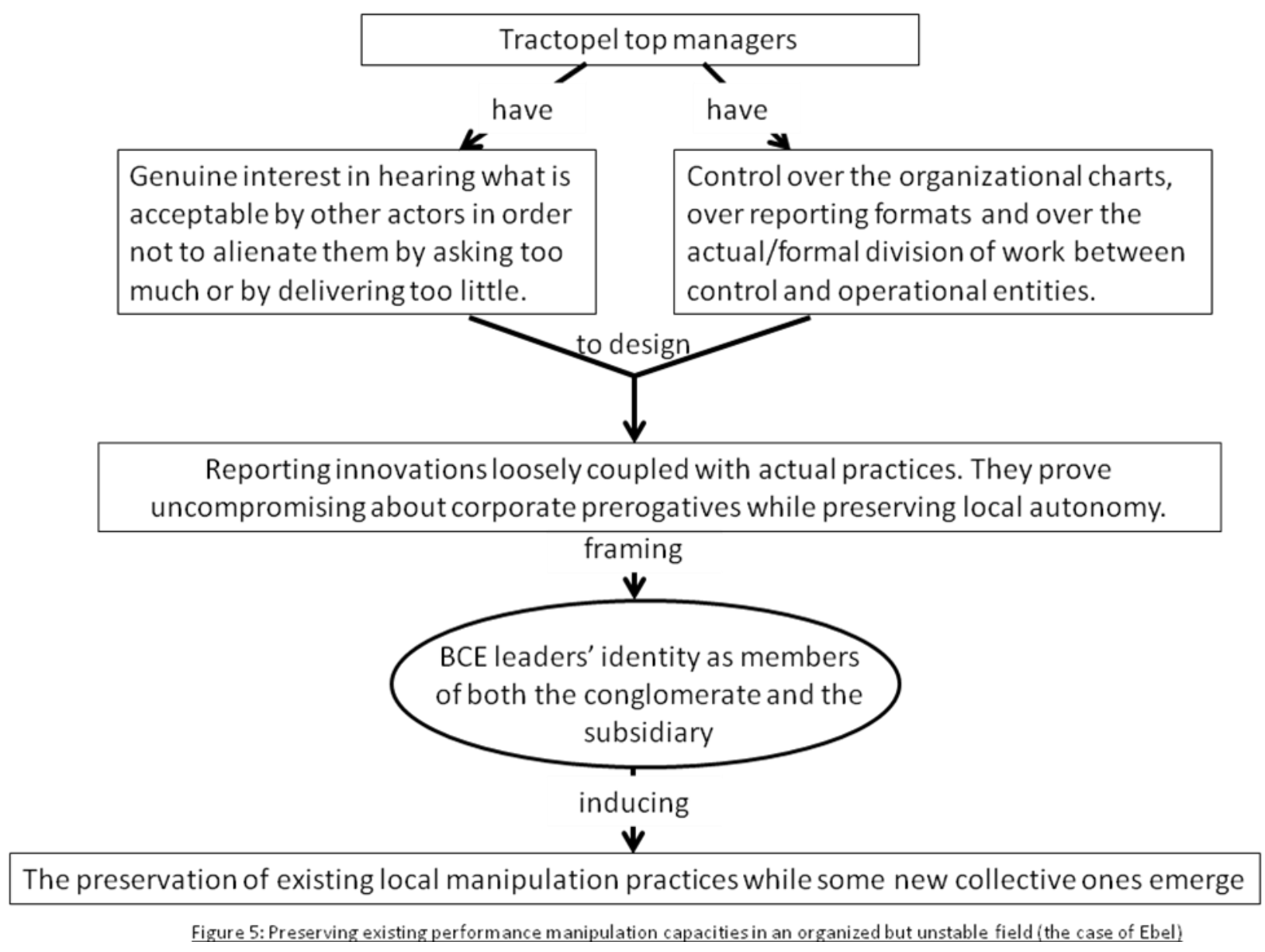

Skilled strategic actors have many constituencies to manage if they wish to maintain social cohesion internally and externally. Few of the actors can concentrate exclusively on pursuing 
valued personal interests. Even reasonably stabilized relations do not exclude interactions that redefine the contours of existing routines. For example, BCE's initiative to include an overestimated cost of control in the reporting is in defense of the status quo, while Tractopel introduces some limited changes to reporting procedures. Final arrangements do not depend entirely on the abilities of one skilled actor, but in the capacity for several group leaders to find acceptable compromises between upper level expectations and realistic business potentialities.

\section{Discussion: actors, processes, and stages of performance reporting manipulation practices}

The main argument of the discussion is that performance reporting manipulation practices in conglomerates rely on cooperation between actors whose interactions are to some extent institutionalized. Subsection 7.1. clarifies the role played by group leaders in articulating relatively comparable resources into original local arrangements around performance manipulation practices. Subsection 7.2. shows that group leaders efforts gradually manage to turn emerging techniques for performance manipulation into norms characteristics of stable reporting fields. It is also argued that interactions with other group leaders, as well as occasional external shocks, may nevertheless challenge manipulation routines at any time. Lastly, subsection 7.3. contributes to enrich Fligstein's framework by analysing the role played by arenas for manipulation where face-to-face encounters preserve the group leaders' ability to think "outside of their own heads" (Fligstein and McAdam 2001: p.7).

\subsection{The role of group leaders in designing original manipulation practices.}

Although the need to exert control over reporting figures is strongly motivated by upper level managers' attitudes, the exact nature of manipulation practices is not imposed from the top, but left to the judgment and ingenuity of local leaders. Actual solutions to compensate for business uncertainties will differ from one sector of a conglomerate to the other. Somewhat similar skills are used in different ways according to the context. In all three situations observed, group leaders' social skills consist of taking other actors' interests into account. They know what to expect from their interlocutors concerning reporting issues and concerns, and they set the conditions for cooperation between actors to become the norm. 
[INSERT CHART 2 ABOUT HERE]

\begin{tabular}{|c|c|c|c|}
\hline Skilled social actors & Ronelec vice-CEOs & BCE executives & Ebel managers \\
\hline Field structure & Unorganized & Organized \& stable & Organized \& unstable \\
\hline Main social skills & $\begin{array}{l}\text { Appreciate other } \\
\text { actors' mentality as } \\
\text { potential allies or } \\
\text { opponents }\end{array}$ & $\begin{array}{l}\text { Mitigate and articulate } \\
\text { the demands of } \\
\text { engineers and group } \\
\text { managers }\end{array}$ & $\begin{array}{l}\text { Listen to other } \\
\text { groups' evolving } \\
\text { interests and estimate } \\
\text { which concessions are } \\
\text { possible or not }\end{array}$ \\
\hline Main resources & $\begin{array}{l}\text { - Nominate people } \\
\text { to key positions } \\
\text { - Implement new } \\
\text { formal meetings }\end{array}$ & $\begin{array}{l}\text { - Control over HR and } \\
\text { incentives policies } \\
\text { - Control over } \\
\text { Information Systems }\end{array}$ & $\begin{array}{l}\text { - Control over formal } \\
\text { reporting procedures } \\
\text { and communication } \\
\text { channels }\end{array}$ \\
\hline Main tactics & $\begin{array}{l}\text { - Define sub-groups' } \\
\text { membership, } \\
\text { interests and } \\
\text { identities } \\
\text { - Assert uncertainty } \\
\text { as an issue and } \\
\text { manipulation as a } \\
\text { solution }\end{array}$ & $\begin{array}{l}\text { - Favor collective } \\
\text { targets over personal } \\
\text { incentives } \\
\text { - Play one group versus } \\
\text { the other } \\
\text { - Centralization of the } \\
\text { use of financial } \\
\text { reserves }\end{array}$ & $\begin{array}{l}\text { - Loose-coupling } \\
\text { between reporting } \\
\text { and operations } \\
\text { - Overtly partly } \\
\text { compromise with } \\
\text { some of one's own } \\
\text { interests }\end{array}$ \\
\hline $\begin{array}{l}\text { Impact of } \\
\text { performance } \\
\text { manipulation } \\
\text { practices }\end{array}$ & $\begin{array}{l}\text { Emergent, they are } \\
\text { gradually stabilized } \\
\text { and form } \\
\text { connections within } \\
\text { groups with shared } \\
\text { interests and } \\
\text { identities }\end{array}$ & $\begin{array}{l}\text { Very stable, they are } \\
\text { taken-for-granted and } \\
\text { are characteristic of } \\
\text { sub-groups with partly } \\
\text { different interests and } \\
\text { identities }\end{array}$ & $\begin{array}{l}\text { Some practices are } \\
\text { left unchanged, } \\
\text { others evolve } \\
\text { balancing inter-group } \\
\text { relations between } \\
\text { integration and } \\
\text { autonomy }\end{array}$ \\
\hline Manipulation arena & The axe committee & Inter-BU meetings & Discussions on RAFs \\
\hline
\end{tabular}

Chart 2: Systematic comparison of the three illustrations

The three illustrations show how different group leaders in conglomerates set up the conditions for other actors to take part in manipulative schemes that satisfy the institutional demand for performance stability and reliability. The case illustrates how collective actions to control performance reporting rely on combinations of resources that are meshed together. For example, BCE leaders are successful in their attempt to orchestrate the centralized use of financial "buffers" created by the engineers because they limit the possibilities of conflicting interests by avoiding individual assessments; because they promote values and display a professional identity shared by those with whom they want to cooperate; and they artificially neutralize the reporting of actual information for long periods of time. In conglomerates, access and control over such a large array of resources is unique 
to leaders of sub-units with positions of authority. Performance manipulation practices are promoted and structured by managers presiding over organizational structures, recruitments, nominations, incentive policies, communication channels, management accounting tools, etc. They enforce their power in the field through managerial technology (Armstrong 2000) and solidify their position through objectified control procedures (Colignon and Covaleski 1988; Hopwood 1984). Yet group leaders use their power position mostly to frame others' interests and identities and seldom impose decisions against the will of other organizational actors. For example, subordinates such as BCE engineers are invited to associate their own success with that of upper levels so that they can supply their superiors with accurate information about financial cushions (Dunk and Perera 1997). Successful cooperation in this situation relies on actors' adhesion to shared values and objectives. Conversely, Ronelec maintenance people do not necessarily share the values and objectives of their superiors, but they find acceptable arrangements in discussions with people who are able to make compromises. Their involvement is solidified because they consider decision-making processes legitimate. In both cases, it is the group leaders' skilful combination of resources that allow such a diverse range of adequate tactical solutions.

It is unrealistic to try to provide an exhaustive list of tactics employed in support of collective manipulation practices. Despite the fact that group leaders have control over relatively comparable resources (all of them hold power positions as BU managers) differences can be explained by their opportunistic reading of the context that open up various tactical possibilities for orchestrating original manipulation practices. For example, Ronelec and BCE have very distinct trajectories considering the extent to which business operations are impacted following their integration in the Ebel conglomerate. Ronelec substantially transformed its management to conform to performance expectations, while BCE seems to rely extensively on accounting tricks. Ronelec had more to gain from major operational restructuring because hardly any attention was paid to business profitability prior to the buyout. Huge performance improvements are obtained by effectively controlling expenses and changing production methods and sales strategies. "Real performance smoothing" solutions impacting maintenance policies are implemented as a complementary device to even out rapidly growing profits. Conversely, BCE was already a for-profit company prior to the buy-out, and improvements due to the rationalization of operations were not as 
dramatic. Better control of expenses and sales were rapidly supplemented by "account" manipulation opportunities offered by international civil engineering contracts. In all situations, facing the challenge of delivering good and predictable performance outputs, group leaders devise manipulation practices that make the most of unique business characteristics and take into consideration the expectations from the upper level and the characteristics of their supporters in the periphery simultaneously.

\subsection{The institutionalization process of performance reporting manipulation practices}

The conclusions of this paper go beyond those of studies that could not disentangle unintended effects and what top management tolerates or encourages (Merchant 1990: p.311). The three illustrations show that managers of parent companies use their authority and influence as resources to diffuse the idea that it is a priority for subsidiaries to deliver good economic outputs in line with pre-approved forecasts. Fligstein's framework clarifies how group leaders learn about and influence other actors' identities and interests to anticipate their reactions and secure their commitment to manipulation practices. Corporate managers do not merely tolerate manipulations because they happen to reduce chances that targets are missed (Van der Stede 2001); they deliberately stimulate performance enhancement solutions. The active role played by group leaders is more explicit in unorganized fields when rules for manipulation are emerging. In the early stages of a work relationship, such as when newly acquired companies enter a conglomerate, corporate managers' concerns are to increase awareness in the periphery about forecast accuracy and performance expectations. Actors nominated by the parent company are "change entrepreneurs" (Castel and Friedberg 2010) positioned at the intersection of interdependent fields (the parent company and the subsidiary), who assert uncertainties in performance reporting as a major problem and simultaneously outline resources to solve it. The influence of financial markets and parent companies is therefore not just relayed by tools and indicators, but is also embodied, at least temporarily, in people. Their work to implement new norms, tools and procedures for engaging others in performance reporting gradually makes manipulation practices ordinary collective management techniques.

Gradually, the original manipulation practices become routine. For example, the Ronelec and BCE illustrations indicate the construction of spaces where the different actors involved in 
manipulations meet on a regular basis. BCE leaders meet with engineers and discuss the financial reserves at their disposal. Ronelec executives introduce a committee to discuss the maintenance schedule. Both situations illustrate the existence of "institutional space where the aggressiveness of earnings management and its acceptability are deliberated" (Okamoto 2011). Such arenas are not places where new solutions emerge, but where existing modalities of cooperation to exert control over financial reporting are collectively enacted. Manipulations thus become institutionalized, as they happen in stable (formal or informal) institutions with explicit regular timing and membership.

It is known that a process of institutionalization is not completed without internalization by the actors (Dambrin et al. 2007). The massive diffusion of manipulation practices is a symptom of the internalization of an institutional expectation (Sauder and Espeland 2009). In conglomerates, such institutional expectation comes from the need to comply with financial markets' unrealistic demands. The institutionalization of performance reporting manipulation practices is thus part of a wider institutionalization process concerning the ideal of perfect forecast reliability. Institutional expectations about performance reporting are simultaneously seductive and coercive (Sauder and Espeland 2009). In the context of conglomerates, performance reporting requirements are seductive because they provide actors with unambiguous objectives associated with rewards such as bonuses or autonomy. They are coercive because those who will not play the game of certainty are easily excluded from the field. The article is not arguing that there is a linear process of institutionalization that would be similar to all relationships between parent companies and subsidiaries. No field is ever entirely institutionalized. Additional norms are found in interactions following external shocks or internal challenges like between Panam, Ebel and BCE. Fields like conglomerates are thus likely to be occasionally partially disorganized until new rules and stable arrangements, including manipulative practices, are adopted.

\subsection{Implementing arenas for collective manipulation practices in support of renewed social skills.}

The article's findings contradict agency theorists who consider that local managers smooth the period's income towards its ex ante expected value because their actions are unobservable by the principal (Lambert 1984). This is an oversimplified view that wrongly 
assumes a hard and fast opposition between control agencies such as parent company managers and agents in the subsidiaries. Group leaders who hold the position of "change entrepreneurs" typically occupy an intermediate position between principal and agent. They do not play one party against the other, but struggle to accommodate their respective interests and identities in a context of performance uncertainties. Applying Fligstein's framework to performance manipulation practices demonstrates that superior knowledge of other people's interests and identities is not used to deceive them with manipulated figures but rather to encourage them to act collectively. As suggested by Lambert (2001), the principal is not necessarily fooled by manipulations. Actors in such contexts are not constantly trying to outwit others (cf. Fudenberg and Tyrole 1995; Dye 1988, Gul et al. 2003); rather, they are participating in long-term cooperation, maintaining the cohesion of the groups in which they participate and reinforcing the robustness of relationships with other groups with which they interact. Managers at different organizational levels are pleased with techniques that offer much appreciated certainty to the consolidated performance of the conglomerate and secure autonomy in the periphery. Fligstein's framework reveals how shaping, aggregating and meeting others' interests through collective performance manipulation practices trigger strong associations (as between BCE engineers) but also distant ones (such as between Ronelec engineers and Ronelec finance people). Such practices draw boundaries and connections, offering sable rules to bring different actors in contact while preserving their distinctiveness. The success of conglomerates' managers therefore rests on their ability to reduce friction between interest groups.

This study also illustrates some tactics that are not usually associated with performance manipulation among which the group leaders' ability to organize arenas for discussions between participants taking part in performance manipulations. This tactic serves different purposes simultaneously. First, it visibly associates others with manipulation practices reinforcing group members' experience of interdependence. Second, such arenas are also excellent opportunities for group leaders to keep in direct contact with other actors. According to Fligstein, group leaders' most important social skills consist of taking other actors' interests into account. A limitation of Fligstein's framework is nevertheless to ignore the origin of such social skills. The present study suggests that regular face-to-face contact is useful for cultivating links with people and better grasping their interests and identities. 
Tactics such as the capacity to compromise with the wider system, the sense of what is possible and impossible in organizing the field, and the ability to take other actors' constraints and expectations into account (Fligstein 1997) all rely on intimate knowledge of interlocutors acquired from prior contacts. Direct encounters preserve leaders' ability to think as if they were a different person in the field by collecting first-hand information about other actors' hopes, beliefs and concerns. It sustains social abilities such as empathy and the capacity to anticipate others' reaction.

Fligstein suggests that it is possible for skilled actors to "fabricate new institutions" designed to stabilize dominant positions (2001). This article shows that institutions like arenas for manipulation participate in the stabilization of relations by providing group leaders with unmediated access to other actors. It suggests that group leaders' social skills are not intrinsic capacities but the result of regular exposure to other people's reasoning, interests, fears, comments, etc. Top executives at BCE and Ronelec take the opinions of engineers and maintenance people into account in their discussions, and they keep track of changes through feedback. Lasting social skills are grounded in immediate regular contacts with a variety of other actors in the field.

\section{Concluding comments}

The article's main theoretical contribution is to present manipulation practices as processes of institutionalization gradually stabilizing actors' positions in conglomerates by providing rules ordering intra and inter-group relationships. More precisely, it argues that BU executives initiate manipulation practices in emerging relations between their parent company and their subsidiaries; practices that become ordinary managerial routines reducing performance uncertainties. The research goes beyond existing quantitative studies on earning management and profit manipulation by examining the actual handling of manipulation techniques by organizational actors. The case illustrates how the tactics implemented to control performance reporting rely on original combinations of a variety of resources that are meshed together by skilful and powerful leaders. For example, performance manipulation practices are implemented using careful restructuring of the organizational structures, new recruitments, good command over IS and management accounting procedures as well as sound knowledge of operations. In conglomerates, access 
to such a large array of resources is unique to leaders of sub-units, and opens up various possibilities for orchestrating original manipulation practices. Far from enacting the same scripts, unit managers find original ways to buffer their group's performance from uncertainties. An empirical contribution of the article is that it analyzes how group leaders invent tactics not usually associated with performance manipulation. It illustrates how arenas for discussion, where participants in manipulation practices meet face-to-face on a regular basis, are an important device for helping group leaders continuously learn about and influence other actors' interests and identities. The concept of "social skills" emphasizes executives' ability to modify other actors' preferences so they can set up the conditions needed for cross-level cooperation. It is thus argued that the required skills for group leaders are "governing" ones: they engage other managers in collective action rather than merely force them into cooperation.

This study is far too restricted to offer a comprehensive description of performance reporting manipulation practices. It nonetheless suggests interesting avenues for further research. Although it was possible to illustrate different stages of the institutionalization process of manipulation practices using multiple cases, this article calls for further research using longitudinal analysis. In addition, the cases presented here all deal with profitable entities. Specific resources, tactics and skills associated with long periods of time including economic downturns when manipulation practices can no longer suffice to meet expectations remain largely unexplored. Finally, the interviews were conducted in a conglomerate listed on the stock exchange where market expectations are known to be extremely influential. It was not possible to interview people in Panam working in direct contact with financial markets. A better understanding of processes leading to the emergence and stabilization of reporting manipulation practices should include an analysis of the relationships between board members, financial communication professionals, analysts and fund investors.

\section{Acknowledgements}

The author acknowledges the helpful comments and stimulating suggestions from two anonymous reviewers. Earlier versions of the article have also benefited from suggestions by Annick Bourguignon, Grant Michelson, Martin Messner, and Keith Robson. Lastly, the author 
acknowledges financial support provided by "Le Pôle Interdisciplinaire d'Etudes Françaises" of the Leopold-Franzens-Universität Innsbruck and the Interdisciplinary Perspective on Accounting team's hospitality at Cardiff Business School (January-June 2011). The usual disclaimers apply. 


\section{Appendixes}

\section{Appendix 1}

List of interviews related to Ebel France, Ronelec, Tractopel and BCE

$\begin{array}{cll}\mathrm{N}^{\circ} & \text { Function } & \text { Company } \\ & & \\ 1 & \text { Vice-CEO interview no. 1 } & \text { BCE } \\ 2 & \text { CEO } & \text { BCE } \\ 3 & \text { CFO } & \text { BCE } \\ 4 & \text { Vice-CEO interview no. 2 } & \text { BCE } \\ 5 & \text { CEO } & \text { Tractopel } \\ 6 & \text { Management accountant } & \text { Tractopel } \\ 7 & \text { Vice-CEO production } & \text { Ronelec } \\ 8 & \text { Vice-CEO finance } & \text { Ronelec } \\ 9 & \text { Management accountant } & \text { Ebel France } \\ 10 & \text { CFO } & \text { Ronelec } \\ 11 & \text { Project manager } & \text { Ebel France }\end{array}$

\section{Appendix 2}

Interview guidelines

- What does your job entail? What are you responsible for?

- Could you briefly describe who is doing what in terms of operations and management?

- What are the main values promoted by your company? What are the guidelines?

- Who are the shareholders of your company?

- Are you in contact with other companies of the conglomerate? When?

- What kind of contact do you have with management accountants? [for non-financial people]

- What do you pay attention to as management accountants? [for finance department people]

- What are the templates used for reporting and control? How often? Who is the audience?

- How is the budgetary process organized? Who decides on financial arbitrations? What are the most problematic aspects of reporting?

- Are there any incentive policies based on performance indicators?

- Are you in contact with external and internal auditors? How often and when?

- What is you educational background? Please describe your career path.

Interview add-ons when manipulative practices were not addressed during the first hour of discussion

- What kind of accruals do you have in the company? When are they set aside and used? 
- Are there any solutions to offset major market variations or unexpected events impacting your performance?

\section{References}

Aglietta M, Reberioux A. Corporate governance adrift. Cheltenham: Edward Elgar; 2005.

Armstrong P. Designing accountability: the managerial semiotic project. Critical Perspectives on Accounting 2000; 11:1-22.

Barton J. Does the use of financial derivatives affect earnings management decisions? The Accounting Review 2001; 76: 1-26.

Beidleman CR. Income smoothing: The role of management. The Accounting Review 1973; 48:653-667.

Bourdieu P. Outline of a Theory of Practice. Cambridge and New York: Cambridge University Press; 1977.

Brunsson N. The organization of hypocrisy. Talk, decision and actions in organizations. Chichester: John Wiley and sons; 1989.

Castel P, Friedberg E. Institutional change as an interactive process: The case of the modernization of the French cancer centers. Organization Science 2010; 21:311-330.

Cheng J, Kesner I. Organizatonal slack and response to environmental shifts: the impact of ressource allocation patterns. Journal of management 1997; 23: 1-18.

Colignon R, Covaleski MA. An examination of managerial accounting practices as a process of mutual adjustment. Accounting Organizations and Society 1988; 13: 559-579.

Covaleski MA, Dirsmith MW, Michelman JE. An institutional theory perspective on the DRG framework, case-mix accounting systems and health-care organizations. Accounting Organizations and Society 1993; 18:65-80.

Cyert R, March J. A behavioral theory of the firm. Englewood cliffs, NJ: Prentice Hall; 1963

Dambrin C, Lambert C, Sponem S. Control and change - Analysing the process of institutionalisation. Management Accounting Research 2007; 18: 172-208.

DeFond ML, Park CW. Smoothing income in anticipation of future earnings. Journal of Accounting and Economics 1997; 23:115-139.

Dunk AS, Perera $\mathrm{H}$. The incidence of budgetary slack: a field study exploration. Accounting, Auditing and Accountability Journal 1997; 10: 649-664.

Dye RA. Earnings management in an overlapping generations model. Journal of Accounting Research 1988; 26:195-235.

Ezzamel M, Robson K, Stapleton P, McLean C. Discourse and institutional change: 'Giving accounts' and accountability. Management Accounting Research 2007; 18:150-171.

Ezzamel M, Willmott $\mathrm{H}$, Worthington F. Manufacturing shareholder value: The role of accounting in organizational transformation. Accounting Organizations and Society 2008; 33:107-140. 
Fligstein N. Social skill and institutional theory. American Behavioral Scientist 1997; 40: 397405.

Fligstein N. Social skill and the theory of the fields. Sociological theory 2001; 19: 105-125.

Fligstein N, McAdam D. Towards a general theory of strategic action fields. Sociological theory 2011; 29: 1-26.

Fundenberg D, Tirole J. A theory of income and dividend smoothing based on incumbency rents. Journal of Political Economy 1995; 103(1):75-93.

Ghosh D, Olsen L. Environmental uncertainty and managers' use of discretionary accruals. Accounting Organizations and Society 2009; 34:188-205.

Glaser BG, Strauss AL. The discovery of grounded theory: Strategies for qualitative research. Chicago: Aldine Publishing Company; 1967.

Goel MA, Thakor AV. Why do firms smooth earnings? The Journal of Business 2003; 76:151193.

Gourevitch P. Collective action problems in monitoring managers: The Enron case as a systemic problem. Economic Sociology, European Economic Newsletter 2002; 3: 3-16.

Graham JC, Harvey CR, Rajgopal S. The economic implications of corporate financial reporting. Journal of Accounting and Economics 2005; 40:3-73.

Gul F, Chen C, Tsui J. Discretionary accounting accruals, managers' incentives, and audit fees. Contemporary Accounting Research 2003; 20:441-464.

Healy P. The effect of bonus schemes on accounting decisions. Journal of Accounting and Economics 1985; 7:85-107.

Healy P, Wahlen J. A review of the earnings management literature and its implications for standard setting. Accounting Horizons 2000:365-383.

Hopwood A. Accounting and the pursuit of efficiency. In A. Hopwood \& C. Tomkins (Eds.), Issues in public sector accounting: Philip Klein; 1984.

Jensen MC. Corporate budgeting is broken - Let's fix it. Harvard Business Review 2001; 79(11): 94-101.

Kirschenheiter M, Melumad N. Can Big Bath and earnings smoothing co-exist as equilibrium financial reporting strategies? Journal of Accounting Research 2002; 40:761-796.

Kothari SP, Leone A, Wasley C. Performance matched discretionary accruals. Journal of Accounting and Economics 2005; 39:161-197.

Lambert RA. Income smoothing as rational equilibrium behavior. The Accounting Review 1984, 59:604-618.

Lambert RA. Contracting Theory and Accounting, Journal of Accounting and Economics 2001; 32:3-87.

Lambert C, Sponem S. Corporate governance and profit manipulation: A French field study. Critical Perspectives on Accounting 2005; 16:717-748. 
Macintosh NB. The ethics of profit manipulations: a dialectic of control analysis. Critical Perspectives on Accounting 1995; 6:289-315.

Macintosh NB. Commentary: accounting- truth, lies, or bullshit? a philosophical investigation. Accounting and the Public Interest 2006;6:22-36.

Macintosh NB. Accounting and the truth of earnings reports: philosophical considerations. European Accounting Review 2009; 18(1):141-75.

Merchant K. A. The effects of financial controls on data manipulation and management myopia. Accounting Organizations and Society 1990; 15:297-313.

Meyer JW, Rowan B. Institutionalized Organizations: Formal structure as myth and ceremony. American Journal of Sociology 1977; 83:340-363.

Moses DO. Income smoothing and incentives: Empirical tests using accounting changes. The Accounting Review 1987; 42:358-377.

Okamoto N. Collective intentionality and aggressive earnings management: developing Norman Macintosh's arguments in the debate over principles- versus rules-based accounting standards. Critical Perspectives on Accounting 2011; 22:236-242.

Roberts J. Strategy and accounting in a UK conglomerate. Accounting Organizations and Society $1990 ; 15: 107-126$.

Sauder M, Espeland WN. The discipline of rankings: Tight coupling and organizational change. American Sociological Review 2009; 74: 63-82.

Sharfman MP, Wolf G, Chase RB, Tansik DA. Antecedents of organizational slack. Academy of management review 1988; 13: 601-614.

Tucker JW, Zarowin PA. Does income smoothing improve earnings informativeness? The Accounting Review 2006; 81:251-270.

Van der Stede WA. The effect of corporate diversification and business unit strategy on the presence of slack in business unit budgets. Accounting, auditing and accountability Journal 2001; 14: 30-52.

Watts RL, Zimmerman JL. Positive Accounting Theory. Englewood Cliffs, NJ: Prentice Hall; 1986. 